\title{
Medicina temeljena na dokazima - promjena paradigme u znanosti i kliničkom radu
}

\author{
Evidence-based medicine - paradigm shift in science and clinical \\ practice
}

Prilika da čitavo izdanje časopisa "Medicina Fluminensis" posvetimo medicini temeljenoj na dokazima ili, kako je neki nazivaju, medicini temeljenoj na činjenicama, odnosno, engleski Evidence based medicine (EBM), izazov je koji proističe iz prepoznavanja važnosti ovog segmenta medicine, odnosno pristupa medicini na način koji je temeljen na sintezi i analizi svega što nam je u stručnom i znanstvenom smislu dostupno i ima znanstvenu, ali i metodološku vrijednost. Medicina temeljena na činjenicama postaje nezaobilazna pomoć u kliničkoj praksi. Kao da se s njom događa ono što je pred više od stotinu godina Bertrand Russel govorio o matematici: “... ono što je najbolje u matematici zaslužuje da ne bude naučeno kao zadaća, već asimilirano kao dio svakodnevnog razmišljanja". lako u svojoj osnovi analitika kojom se koristi medicina temeljena na činjenicama ima mnogo statističkih elemenata, ovdje se ne radi o statistici koja bi nas trebala zavaravati - da parafraziram Roba Kingstona - i biti na tragu duhovitih poluistina koje kažu kako postoje laži, proklete laži i statistika, koja jednostavnom nekompetentnom manipulacijom koristi matematiku ${ }^{1}$.

Pridavanjem sve veće važnosti provođenju randomiziranih kontroliranih istraživanja u medicini tijekom devedesetih godina prošlog stoljeća i razvojem novog koncepta medicine temeljene na dokazima dogodila se promjena paradigme u znanstveno-istraživačkom radu i kliničkom pristupu liječenju pacijenata ${ }^{2,3}$. Rezultati i zaključci randomiziranih kliničkih istraživanja i njihove metaanalize počeli su predstavljati vrh piramide znanstvenih i medicinskih dokaza, a na njihovoj su osnovi skupine stručnjaka počele kreirati smjernice i preporuke za dijagnostiku i liječenje specifičnih stanja, koje predstavljaju vodilju u svakodnevnoj kliničkoj praksi, ali i ekonomsko-organizacijskom upravljanju zdravstvenim sustavom.

Implementacija novog pristupa potaknula je prije svih liječnike, ali i druge djelatnike u zdravstvu, na udaljavanje i napuštanje ustaljenih obrazaca razmišljanja i djelovanja, umanjujući pritom važnost patofiziologije kao dovoljne osnove razumijevanja i poznavanja bolesti, nesustavno stečenog kliničkog iskustva i institucijskih granica u donošenju odluka ${ }^{4}$. No, navedene komponente neizostavni su dio razvoja pojedinca kao znanstvenika i liječnika. Medicina temeljena na dokazima svakako ne podrazumijeva negaciju iskustva stečenog u svakodnevnom radu i suradnji s kolegama, iz jednostavnog razloga što u medicini i životu općenito nije moguće sve podvrgnuti testiranju, a svako znanje nije moguće steći znanstvenim istraživanjem². Promjena

http://hrcak.srce.hr/medicina 
paradigme podrazumijeva da iskustvo i autoritet nisu jedini i dovoljni čimbenici za adekvatno donošenje odluka. Sve se više izbjegava medicinsko odlučivanje na temelju tradicije, dogmi i konvencija, a potiče se donošenje odluka na temelju dokaza koji proizlaze iz istraživanja, pri čemu se posebno ističu adekvatno dizajnirana i opsežna randomizirana kontrolirana istraživanja ${ }^{5}$. Brojni su izvori informacija u medicini te svi publicirani materijali predstavljaju dokaz, od prikaza slučaja do metaanalize, ali u procjeni dostupnih informacija i donošenju realnih odluka bitna je razina i kvaliteta postojećih dokaza. Stoga je danas u izradi dijagnostičkih i terapijskih smjernica uobičajena klasifikacija dokaza na temelju kojih je izvedena određena preporuka (tablica 1). Sukladno tome i preporuke se svrstavaju po stupnjevima s obzirom na dokaze, kao i njihov učinak na daljnja istraživanja i kliničku praksu (tablica 2).

Provođenjem randomiziranih kliničkih istraživanja fokus procjene učinkovitosti, odnosno štetnosti određene medicinske intervencije, usmjeren je s do tada uglavnom surogatnih ishoda na klinički relevantne ishode, primarno smrtnost i pobol ${ }^{8}$. Jedan od najvećih pomaka postignut je na području kardiologije. Tako je u radu Echt i sur. objavljenom 1991. godine u časopisu New England Journal of Medicine po prvi put ispitivana hipoteza da supresija ventrikularne ektopije antiaritmijskim lijekovima u pacijenata nakon preboljelog akutnog infarkta miokarda smanjuje učestalost iznenadne srčane smrti ${ }^{9}$. Ustanovljeno je da su u skupini pacijenata liječenih antiaritmicima bila 63 smrtna ishoda na 755 analiziranih pacijenata, dok je u placebo grupi od 743 analizirana umrlo 26 pacijenata $(P=$ $0,0001)^{9}$. Navedeni rezultati, kao i neke druge povezane spoznaje, doveli su ubrzo do potpunog napuštanja kliničke primjene brojnih lijekova iz skupine antiaritmika. Unatoč brojnim ovakvim primjerima nepoznavanja elementarnih koncepata i metoda u medicini temeljenoj na dokazima, kao i skepsa prema njoj, i danas predstavljaju uteg prihvaćanju i implementaciji ovog pristupa u svakodnevnoj kliničkoj praksi. Postoje brojni podaci i

Tablica 1. Razine dokaza (prilagođeno prema ref. 6)

\begin{tabular}{|c|l|}
\hline $1 a$ & Sustavni pregledi randomiziranih kontroliranih studija \\
\hline 1 b & Pojedinačne randomizirane kontrolirane studije \\
\hline 1 c & $\begin{array}{l}\text { Svi ili nitko (npr. svi su pacijenti umrli prije dostupnosti lijeka, ali sada neki preživljavaju uz njegovu pomoć; neki su pacijenti } \\
\text { umirali prije dostupnosti lijeka, ali sada nitko ne umire uz njegovu pomoć) }\end{array}$ \\
\hline $2 a$ & Sustavni pregledi kohortnih studija \\
\hline 2 b & Pojedinačne kohortne studije \\
\hline 2 c & Studije ishoda; ekološke studije \\
\hline $3 a$ & Sustavni pregledi case-control studija \\
\hline $3 b$ & Pojedinačne case-control studije \\
\hline 4 & Case serije (i kohortne i case-control studije loše kvalitete) \\
\hline 5 & Mišljenje stručnjaka bez eksplicitne kritičke procjene ili bazirano na patofiziologiji, bazičnim istraživanjima ili prvom načelu \\
\hline
\end{tabular}

Tablica 2. Stupnjevi preporuka (prilagođeno prema ref. 7)

\begin{tabular}{|c|l|}
\hline A & $\begin{array}{l}\text { Studije razine dokaza } 1 \\
\text { - malo je vjerojatno da će dodatna istraživanja promijeniti našu pouzdanost u procjenu učinka neke intervencije }\end{array}$ \\
\hline B & $\begin{array}{l}\text { Studije razine dokaza } 2 \text { i 3, ili nastale ekstrapolacijom iz studija razine } 1 \\
\text { - dodatna istraživanja potencijalno će imati značajan učinak na našu pouzdanost o učinku neke intervencije i može promijeniti } \\
\text { navedenu procjenu }\end{array}$ \\
\hline C & $\begin{array}{l}\text { Studije razine dokaza } 3 \text { ili nastale ekstrapolacijom iz studija razine } 2 \text { i } 3 \\
\text { - dodatna istraživanja će vrlo vjerojatno imati značajan učinak na našu pouzdanost o učinku neke intervencije i vjerojatno } \\
\text { će promijeniti navedenu procjenu }\end{array}$ \\
\hline D & $\begin{array}{l}\text { Studije razine } 5 \text { ili problematične nekonzistentne i inkonkluzivne studije bilo koje razine } \\
\text { - svaka procjena učinka vrlo je nesigurna }\end{array}$ \\
\hline
\end{tabular}


analize koje ukazuju na vrlo učestalo nepridržavanje liječnika i ostalog medicinskog osoblja aktualnih dijagnostičko-terapijskih smjernica.

lako navedene smjernice ne predstavljaju zakonsku obvezu u radu već isključivo preporuke, te njihovo provođenje ne potiču i ne zahtijevaju ni zdravstvene institucije, one su plod najboljih dostupnih dokaza u medicinskoj literaturi nastalih primjenom principa medicine temeljene na dokazima. Sustavno i neosnovano nepridržavanje predstavlja odstupanje od općeprihvaćenih načela kliničkog rada i brige o pacijentima. Tako je upitnikom koji je proveden 2005. godine na 600 patologa utvrđeno da se samo $12 \%$ osjeća prilično pouzdano identificirati dizajn studije u nekom znanstvenom radu, ali je istovremeno samo $13 \%$ smatralo da njihova nemogućnost interpretacije rezultata istraživanja predstavlja značajnu prepreku u provođenju kliničke prakse temeljene na dokazima 5 .

Izneseni podaci ukazuju na to da je razvoj, implementacija i opstanak medicine temeljene na dokazima bio i jest podvrgnut kritici određenog dijela znanstvene i medicinske javnosti. Sve postojeće definicije i opisi medicine temeljene na dokazima usmjereni su k pacijentima, kao krajnjim korisnicima svih dobrobiti ovog pristupa. No možda najznačajnija kritika upućena je upravo na mogućnost integracije EBM-a u svakodnevnu kliničku praksu, odnosno njeno udaljavanje od samog pacijenta. Brojni izvori u literaturi ukazuju da ovakav pristup ne uzima u obzir specifične karakteristike pojedinog pacijenta, a strogo pridržavanje i provođenje metodologije EBM-a može rezultirati i štetnim djelovanjem po pacijente ${ }^{10}$. Dodatna kritika uključuje mišljenje brojnih kliničara da EBM često zanemaruje važnost iskustva, dok se istovremeno kliničari unatoč preporukama i dostupnim literaturnim dokazima u svome radu nerijetko povode upravo vlastitim iskustvom. Potencijalno najrazboritije i vjerojatno najučinkovitije rješenje predstavlja razvoj lokalnih sustava sistematizacije kliničkog iskustva i njegove inkorporacije s najboljim postojećim globalnim znanstvenim dokazima ${ }^{3}$. EBM zahtijeva i sustavnu edukaciju studenata, liječnika na specijalizaciji i liječnika specijalista, no i edukaciju pacijenata. Uključivanje medicine temeljene na dokazima u kurikulume medicinske edukacije u brojnim sustavima nije ni započeto, dok u drugima zahtijeva bit- ne promjene i dorade. Sustavna pretraga literature s ciljem pronalaska adekvatnih dokaza zahtijeva znanje i vrijeme, a sustavni pregledi ranodomiziranih kliničkih istraživanja predstavljaju potencijalno rješenje. Izneseni podaci ukazuju da unatoč značajnom razvoju EBM-a postoji kontinuirana potreba integracije ovog sustava u svakodnevni rad i kliničko razmišljanje zdravstvenog osoblja.

Ovim tematskim brojem posvećenom medicini temeljenoj na dokazima prije svega nastojimo upoznati medicinsku i širu javnost sa značenjem i položajem ove discipline u današnjem znanstveno-istraživačkom i kliničkom radu. Prikazom rezultata postignutih u Hrvatskoj pokušat ćemo ukazati na dostupnost medicine temeljene na dokazima svima, kao i njenu važnost u adekvatnom vođenju zdravstvenih sustava. lako je naše nastojanje popularizacija medicine temeljene na dokazima, kritičko sagledavanje svijeta, pa tako i same medicine temeljene na dokazima, njezina je bit. Njen razvoj dinamičan je proces uvjetovan još intenzivnijim razvojem medicine uopće, ali budućnost tog razvoja ne smije odstupati od izvornih ideja koje su sažete u njenoj definiciji, da je medicina temeljena na dokazima savjesna, eksplicitna i razborita primjena trenutno najboljih postojećih dokaza pri donošenju odluka o skrbi pacijenta kao pojedinca, koja nastaje integracijom individualnog kliničkog iskustva i kliničkih dokaza koji proizlaze iz sustavnih istraživanja ${ }^{11}$.

Danas, kad studenti poslijediplomskih znanstvenih i poslijediplomskih stručnih studija slušaju predmet Medicina temeljena na činjenicama, ovaj tematski broj zamišljen je kao praktična pomoć u njihovu učenju, ali je namijenjen i svima onima koji se susreću s ovim terminom. Ovim izdanjem željeli bismo izbjeći i nedoumice koje mogu nastati u nedostatku literature na hrvatskom jeziku iz ovog područja. Vjerujemo da će bar neki od čitatelja ovog broja poželjeti postati dio našeg tima i dio svoga vremena u bavljenju medicinom posvetiti upravo medicini temeljenoj na činjenicama.

prof. dr. sc. Davor Štimac doc. dr. sc. Goran Poropat Zavod za gastroenterologiju, Klinika za internu medicinu, Klinički bolnički centar Rijeka 


\section{LITERATURA}

1. Ellenberg J. How not to be wrong: the power of mathematical thinking. New York: Penguin Books, 2015.

2. Evidence-Based Medicine Working Group. Evidence-based medicine. A new approach to teaching the practice of medicine. JAMA 1992;268:2420-5.

3. Hay MC, Weisner TS, Subramanian S, Duan N, Niedzinski EJ, Kravitz RL. Harnessing experience: exploring the gap between evidence-based medicine and clinical practice. J Eval Clin Pract 2008;14:707-13.

4. Lewis SJ, Orland BI. The importance and impact of evidence-based medicine. J Manag Care Pharm 2004;10: S3-5.

5. Glasziou P. Why is evidence-based medicine important? Evid Based Med 2006;11:133-5.

6. www.cebm.net [Internet]. Oxford: Oxford Centre for Evidence-based Medicine [cited 2017 Jun 12]. Available from: http://www.cebm.net/oxford-centre-evidencebased-medicine-levels-evidence-march-2009.

7. Atkins $D$, Best $D$, Briss PA, Eccles $M$, Falck-Ytter $Y$, Flottorp $S$ et al. Grading quality of evidence and strength of recommendations. BMJ 2004;328:1490.

8. Kennedy HL. The importance of randomized clinical trials and evidence-based medicine: A clinician's perspective. Clin Cardiol 1999;22:6-12.

9. Echt DS, Liebson PR, Mitchell LB, Peters RW, Obias-Manno $\mathrm{D}$, Barker $\mathrm{AH}$ et al. Mortality and morbidity in patients receiving encainide, flecainide, or placebo. The cardiac arrhythmia suppression trial. N Engl J Med 1991;324:781-8.

10. Kelly MP, Heath I, Howick J, Greenhalgh T. The importance of values in evidence-based medicine. BMC Med Ethics 2015;16:69.

11. Sackett DL, Rosenberg WM, Gray JA, Haynes RB, Richardson WS. Evidence based medicine: what it is and what it isn't. BMJ 1996;312:71-2. 